\title{
DATA FOR SOME AFRICAN COLUMBITE-TANTALITE SPECIMENS
}

\author{
George A. D. ZeLt
}

ZeLt, A. D. 1975: Data for some African columbite-tantalite specimens. Bull. Geol. Soc. Finland 47, 117-125.

Twenty-three specimens from equatorial and southern Africa are investigated, primarily for $\mathrm{X}$-ray powder data. Unit cell dimensions and volume, ranging from $414.7 \AA^{3}$ (columbite) to $424.1 \AA^{3}$ (manganotantalite) are given. $A$ correlation between the unit cell volume and the $100 \cdot \mathrm{Mn} /(\mathrm{Mn}+\mathrm{Fe})$ ratio is indicated and a further correlation to $100 \cdot \mathrm{Ta} /(\mathrm{Ta}+\mathrm{Nb})$ is suggested.

The degree of order is discussed according to the $\mathrm{a}_{0} / \mathrm{c}_{0}$ ratio. Five originally disordered specimens $\left(\mathrm{a}_{0} / \mathrm{c}_{0}=2.769-2.811\right)$ and ones originally ordered specimen $\left(\mathrm{a}_{0} / \mathrm{c}_{0}=2.832\right)$ were heated at $1,000^{\circ} \mathrm{C}$ for one hour. As a result the $\mathrm{a}_{0} / \mathrm{c}_{0}$ ratio in the disordered specimens increased to $2.829-2.833$, causing the specimens to become ordered and the originally ordered specimen's $\mathrm{a}_{0} / \mathrm{c}_{0}$ ratio decreased to 2.788 .

Three X-ray diffractograms are presented [based on the averages of all diffractograms, and differences in: 1) disordered columbite or tantalite (110 peak may or may not be present, but when it is, it is very weak), 2) ordered Mn-tantalite (110, $200,400,600$, and 023 peaks are primarily much stronger than in columbite or tantalite and the $711+512,421$, and 112 is present in $\mathrm{Mn}$-tantalite but not in columbite or tantalite) and 3) disordered structures transformed into ordered structures $(200,400,600$, and 023 peaks have become more prominent, the $421,711+512$ are now present, and the 112 is not present].

Chemical analyses of some 108 columbite-tantalite specimens (including the specimens examined in this paper) are plotted according to their end members. The specimens approaching the $\mathrm{Mn}$-tantalite end member are well represented.

The atomic ratio $100 \cdot \mathrm{Ta} /(\mathrm{Ta}+\mathrm{Nb})$ of 60 specimens (including the specimens investigated in this paper) are plotted against density. The ratio may be estimated according to the equation $100 \cdot \mathrm{Ta} /(\mathrm{Ta}+\mathrm{Nb})=37.209 \mathrm{~d}-195.4$, where $\mathrm{d}=$ density. The calculated densities of the original 23 specimens are compared with the observed densities.

A. D. Zelt, Department of Geology and Mineralogy, Precambrian Research Unit, University of Cape Town. Cape Town, South Africa. 


\section{Introduction}

In connection with a general review of the rare mineral pegmatites from the orogenic belts of equatorial and southern Africa, v. Knorring (1970, pp. 166 - 167) summarized the data for the chemical composition of some minerals of the columbite-tantalite series from these pegmatites. The list of analyses presented by him represents a compilation of the analytical work carried out by J. R. Baldwin and Dr. v. Knorring himself during a number of years at the Department of Earth Sciences, Leeds University, U. K. No other mineralogical data for the analyzed specimens were reported.

It was known that this valuable collection of original materials was stored in Leeds. Therefore, it seemed desirable to add some information to those specimens, mainly $\mathrm{X}$-ray powder data. On the request of the author, Dr. v. Knorring very kindly made available original materials of 23 columbite-tantalite specimens from which the chemical analyses had been made. These specimens were subjected to laboratory study at the Dept. of Geology and Mineralogy of the University of Helsinki, Finland. The results obtained are presented in this paper.

\section{The Specimens}

Twenty-three analyzed specimens (numbered $1-5$ and $7-24)$ were obtained. The unit cell contents, based on 24 oxygen atoms per cell, were calculated (Table 1) by the author. The specimens have been listed in v. Knorring (1970) and retain in this paper the numbering suggested in that publication. In the same publication, sample No. 15 should read a total of 99.9 for the chemical analysis and the figure for $\mathrm{Ta}_{2} \mathrm{O}_{5}$ for sample No. 19 should read $53.29 \%$. Many of these analyses have been published previously in the Annual Reports (No. 6, 1962; No. 7, 1963; No. 8, 1964; No. 9, 1965; No. 10, 1966; No. 11, 1967; and No.
12, 1968) on Scientific Results, of the University of Leeds, Research Institute of African Geology. Notation has been given indicating the annual report(s) where each analysis has been given. Other references have also been included.

In the literature, the members of the columbite-tantalite series have been referred to by various systems of nomenclature. The proposal by Dana (1946) has been adopted. Several of the original mineral names assigned to the specimens by v. Knorring (ibid.) have been altered to conform to that nomenclature (below). However, the original names have also been included in parentheses:

1. Columbite, Rwemeriro pegmatite, Ankole, S. W. Uganda.

2. Columbite, Rwanza pegmatite, Kabira, Ankole, S. W. Uganda. The 9th (p. 43) and the 12th (p. 51) Annual Report.

3. Columbite, Kabira pegmatite, Ankole, S. W. Uganda. The 8th (p. 12) and 12th (p. 51) Annual Report.

4. Columbite, Kabira pegmatite, Ankole, S. W. Uganda. The 8th (p. 12) and 12th (p. 51) Annual Report.

5. Columbite, Nyabushenyi pegmatite, Ankole, S. W. Uganda. The 11th (p. 37) and 12th (p. 51) Annual Report.

7. Columbite, Nyabakweri pegmatite, Ankole, S. W. Uganda. The 8th (p. 12) and 12th (p. 51) Annual Report.

8. Columbite, Bukangari pegmatite, Kigezi, S. W. Uganda. The 9th (p. 43) and 12th (p. 51) Annual Report.

9. Mn-columbite (originally columbite), Kazumu pegmatite, Ankole, S. W. Uganda.

10. Mn-columbite (originally columbite), Nyabushoro pegmatite, Kigezi, S. W. Uganda. The 9th (p. 43) and 12th (p. 51) Annual Report.

11. Columbite, Kashozo pegmatite, Ankole, S. W. Uganda.

12. Columbite, Bulema pegmatite, Kigezi, S. W. Uganda. The 9th (p. 43) and 12th (p. 51) Annual Report.

13. Columbite, Kayonza pegmatite, Kigezi, S. W. Uganda. The 8th (p. 12) and 12th (p. 51) Annual Report.

14. Columbite, Nyanga pegmatite, Ankole, S. W. Uganda. The 8th (p. 12) and 12th (p. 51) Annual Report.

15. Tantalite, Bulema pegmatite, Kigezi, S. W. Uganda. The 8th (p. 12) and the 12th (p. 51) Annual Report. 
16. Mn-tantalite (originally tantalite), Muiane pegmatite Alto Ligonha, Mozambique. The 9th (p. 43) and 12th (p. 51) Annual Report.

17. Mn-tantalite (originally tantalite), Morrua pegmatite, Alto Ligonha, Mozambique. The 6th (p. 59), 9th (p. 43), and 12th (p. 51) Annual Report.

18. Mn-columbite, Buranga pegmatite, Gatumba, Rwanda. The 11th (p. 37) and 12th (p. 52) Annual Report.

19. Mn-tantalite, Namirrapa pegmatite, Alto Ligonha, Mozambique. The 11th (p. 37) and 12th (p. 52) Annual Report. Note, in each report the figure for $\mathrm{Ta}_{2} \mathrm{O}_{5}$ should read $53.27 \%$.

20. Mn-tantalite, Dernburg pegmatite, Karibib, S. W. Africa. The 7th (p. 72), 9th (p. 43) and 12th (p. 52) Annual Report.

21. Mn-tantalite, Jemubi River, Ankole, S. W. Uganda. The 10th (p. 32) and 12th (p. 52) Annual Report and v. Knorring, O., Sahama, Th. G., and Saari, E. (1966), p. 48.

22. Mn-tantalite, Monrepos pegmatite, Karibib, S. W. Africa. The 10th (p. 32) and 12th (p. 52) Annual Report, and v. Knorring, O., Sahama, Th. G., and Saari, E. (1966), p. 48.

23. Mn-tantalite, Okangava Ost pegmatite, Karibib, S. W. Africa. The 10th (p. 32) and 12th (p. 52) Annual Report.

24. Mn-tantalite, Morrua pegmatite, Alto Ligonha, Mozambique. The 9th (p. 43) and 12th (p. 52) Annual Report.

Figure 1 depicts 108 analyses of various members of the series plotted according to their end members. Ti and Sn were omitted. Specimens approaching the $\mathrm{MnTa}_{2} \mathrm{O}_{6}$ (manganotantalite) end member are well represented. To the knowledge of the author the $\mathrm{FeTa}_{2} \mathrm{O}_{6}$ rich specimens have not been verified as members of the orthorhombic columbite-tantalite series. Other relatively pure end members lack representation in the literature. They are apparently very rare and possibly do not exist in nature as such.

\section{X-ray powder pattern}

The X-ray powder patterns of samples Nos. $1-5$ and $7-24$ were recorded by a Philips wide angle goniometer with a Wallac single channel analyzer using filtered copper radiation and internal silicon standard. A goniometer speed of

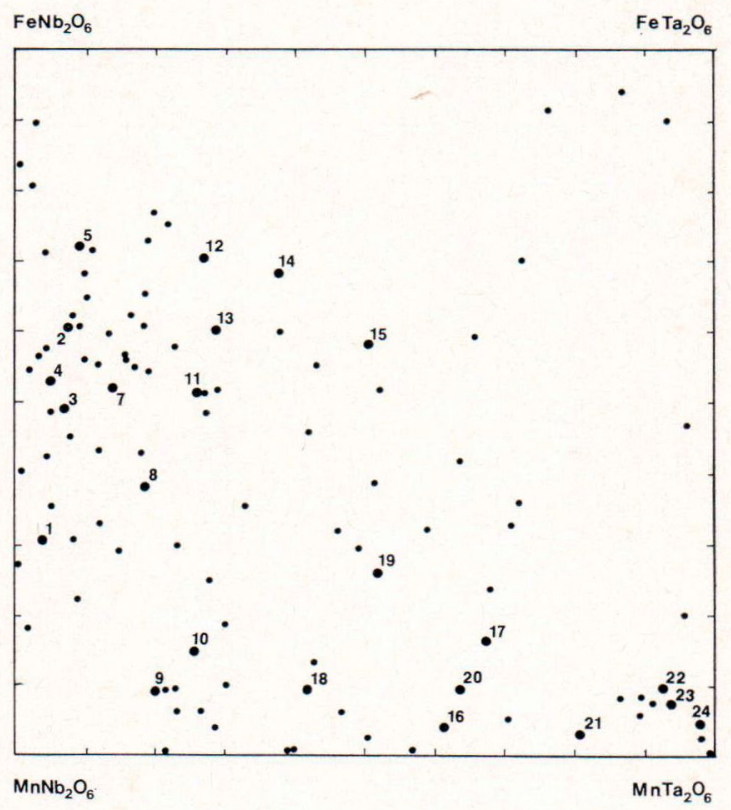

Fig. 1. Compositions of specimens Nos. $1-5$ and $7-24$ plotted according to the end members of the columbitetantalite series. The numbering refers to TABLE 1. For comparison, compositions of 85 columbite-tantalite specimens from various sources in the literature have been added (not numbered).

$2 \mathrm{~min} . /$ degree and chart speed of $40 \mathrm{~mm} /$ degree was employed. Each sample was recorded at least twice and the average $\mathrm{d}$-values for each line were adopted. The unit cell dimensions were calculated by the least-squares method. The setting proposed by Laves et al. (1963) corresponding to the space group Pbcn was used. In this setting the approximate unit cell dimensions are as follows:

$$
\begin{aligned}
& \mathrm{a}_{0} \sim 14.2 \AA \\
& \mathrm{b}_{0} \sim 5.7 \\
& \mathrm{c}_{0} \sim 5.1
\end{aligned}
$$

All measurable peaks on the chart of a single sample were included in the calculation of the unit cell dimensions of that particular sample. This method of measuring the chart was considered to yield more accurate results than a measurement of a standard fixed group of peaks applied to every chart. 
TABle 1.

Unit cell contents (based on $0=24$ ), unit cell parameters and densities of specimens Nos. $1-5$ and $7-24$ investigated in this paper. Analysts: J. R. Baldwin and Oleg v. Knorring

\begin{tabular}{|c|c|c|c|c|c|c|c|c|}
\hline & 1 & 2 & 3 & 4 & 5 & 7 & 8 & 9 \\
\hline $\mathrm{Nb} \ldots \ldots \ldots \ldots$ & 7.37 & 7.18 & 7.09 & 7.20 & 7.14 & 6.87 & 6.51 & 6.39 \\
\hline $\mathrm{Ta} \ldots \ldots \ldots \ldots \ldots$ & 0.30 & 0.58 & 0.51 & 0.74 & 0.73 & 1.11 & 1.48 & 1.59 \\
\hline Ti $\ldots \ldots \ldots \ldots \ldots$ & 0.33 & 0.24 & 0.40 & - & 0.15 & - & - & - \\
\hline $\mathrm{Sn} \ldots \ldots \ldots \ldots \ldots$ & 0.05 & 0.06 & 0.09 & 0.08 & 0.03 & 0.01 & - & 0.03 \\
\hline $\mathrm{Mn} \ldots \ldots \ldots \ldots \ldots$ & 2.83 & 1.57 & 2.05 & 1.88 & 1.09 & 1.92 & 2.73 & 3.61 \\
\hline $\mathrm{Fe} \ldots \ldots \ldots \ldots \ldots$ & 1.24 & 2.44 & 1.97 & 2.11 & 2.88 & 2.12 & 1.30 & 0.37 \\
\hline$a_{0}(\AA) \quad \ldots \ldots \ldots \ldots$ & 14.291 & 14.263 & 14.204 & 14.212 & 14.271 & 14.212 & 14.341 & 14.343 \\
\hline$b_{0}(\AA) \quad \ldots \ldots \ldots \ldots$ & 5.739 & 5.729 & 5.715 & 5.722 & 5.735 & 5.728 & 5.745 & 5.752 \\
\hline$c_{0}(\AA) \quad \ldots \ldots \ldots \ldots$ & 5.112 & 5.095 & 5.109 & 5.105 & 5.067 & 5.124 & 5.093 & 5.126 \\
\hline$V\left(\AA^{3}\right) \ldots \ldots \ldots \ldots$ & 419.3 & 416.2 & 414.7 & 415.1 & 414.7 & 417.2 & 419.6 & 422.9 \\
\hline$a_{0} / c_{0} \ldots \ldots \ldots \ldots \ldots$ & 2.795 & 2.799 & 2.780 & 2.784 & 2.815 & 2.773 & 2.816 & 2.800 \\
\hline Density calc. . . & 5.42 & 5.57 & 5.55 & 5.90 & 5.65 & 5.76 & 5.85 & 5.84 \\
\hline measured $\ldots \ldots \ldots$ & 5.44 & 5.53 & 5.39 & 5.56 & 5.66 & 5.55 & 5.77 & 6.30 \\
\hline
\end{tabular}

\begin{tabular}{|c|c|c|c|c|c|c|c|c|}
\hline & 10 & 11 & 12 & 13 & 14 & 15 & 16 & 17 \\
\hline $\mathrm{Nb} \ldots \ldots \ldots \ldots \ldots$ & 5.98 & 5.78 & 5.84 & 5.69 & 4.76 & 3.87 & 3.04 & 2.50 \\
\hline Та $\ldots \ldots \ldots \ldots \ldots$ & 2.03 & 2.00 & 2.15 & 2.28 & 2.88 & 3.97 & 4.93 & 5.26 \\
\hline Ti $\ldots \ldots \ldots \ldots \ldots$ & - & 0.23 & - & - & 0.48 & 0.19 & - & 0.28 \\
\hline sn $\ldots \ldots \ldots \ldots \ldots$ & 0.04 & 0.05 & 0.04 & 0.03 & 0.04 & 0.05 & 0.03 & 0.05 \\
\hline $\mathrm{Mn} \ldots \ldots \ldots \ldots$ & 3.35 & 1.94 & 1.16 & 1.60 & 1.21 & 1.65 & 3.84 & 3.30 \\
\hline $\mathrm{Fe} \ldots \ldots \ldots \ldots \ldots$ & 0.58 & 2.06 & 2.82 & 2.42 & 2.64 & 2.29 & 0.17 & 0.66 \\
\hline$a_{0}(\AA) \quad \ldots \ldots \ldots \ldots$ & 14.350 & 14.245 & 14.280 & 14.282 & 14.235 & 14.283 & 14.272 & 14.272 \\
\hline$b_{0}(\AA) \ldots \ldots \ldots \ldots$ & 5.750 & 5.737 & 5.735 & 5.738 & 5.730 & 5.736 & 5.745 & 5.748 \\
\hline$c_{0}(\AA) \quad \ldots \ldots \ldots \ldots$ & 5.105 & 5.124 & 5.077 & 5.100 & 5.115 & 5.075 & 5.155 & 5.154 \\
\hline $\mathrm{V}\left(\AA^{3}\right) \ldots \ldots \ldots \ldots$ & 421.2 & 418.8 & 415.8 & 418.0 & 417.2 & 415.9 & 422.7 & 422.7 \\
\hline$a_{0} / c_{0} \ldots \ldots \ldots \ldots \ldots$ & 2.811 & 2.780 & 2.813 & 2.800 & 2.782 & 2.814 & 2.769 & 2.769 \\
\hline Density calc. ...... & 6.02 & 6.03 & 6.15 & 6.16 & 6.33 & 6.76 & 7.00 & 7.09 \\
\hline measured ........ & 6.04 & 5.85 & 5.93 & 6.05 & 6.52 & 5.86 & 7.00 & 7.04 \\
\hline
\end{tabular}

\begin{tabular}{|c|c|c|c|c|c|c|c|c|}
\hline & 18 & 19 & 20 & 21 & 22 & 23 & 24 & \\
\hline $\mathrm{Nb}$ & 4.64 & 3.75 & 2.86 & 1.54 & 0.58 & 0.49 & 0.15 & $a_{0}=+.01 \quad(\AA)$ \\
\hline $\mathrm{Ta} \ldots \ldots \ldots \ldots$ & 3.33 & 4.08 & 5.10 & 6.46 & 7.42 & 7.49 & 7.82 & $\mathrm{~b}_{0}= \pm .005(\AA)$ \\
\hline $\mathrm{Ti} \ldots \ldots \ldots \ldots \ldots$ & - & - & 0.14 & - & 0.02 & - & - & $\mathrm{c}_{0}= \pm .003(\AA)$ \\
\hline $\mathrm{S} n \ldots \ldots \ldots \ldots \ldots$ & - & 0.23 & - & - & - & - & 0.14 & \\
\hline $\mathrm{Mn} \ldots \ldots \ldots \ldots$ & 3.69 & 2.94 & 3.45 & 3.88 & 3.58 & 3.73 & 3.79 & \\
\hline $\mathrm{Fe} \ldots \ldots \ldots \ldots$ & 0.39 & 1.04 & 0.36 & 0.14 & 0.41 & 0.31 & 0.19 & \\
\hline$a_{0}(\AA) \ldots$ & 14.385 & 14.360 & 14.419 & 14.438 & 14.437 & 14.428 & 14.417 & \\
\hline$b_{0}(\AA) \ldots \ldots \ldots \ldots$ & 5.754 & 5.751 & 5.767 & 5.770 & 5.769 & 5.765 & 5.760 & \\
\hline$c_{0}(\AA) \ldots \ldots \ldots \ldots$ & 5.105 & 5.094 & 5.092 & 5.091 & 5.093 & 5.096 & 5.092 & \\
\hline$V\left(\AA^{3}\right) \ldots \ldots \ldots \ldots$ & 422.5 & 420.7 & 423.3 & 424.1 & 424.1 & 423.9 & 422.9 & \\
\hline$a_{0} / c_{0} \ldots \ldots \ldots \ldots \ldots$ & 2.818 & 2.819 & 2.832 & 2.838 & 2.835 & 2.832 & 2.831 & \\
\hline Density calc. .. & 6.45 & 6.71 & 7.02 & 7.50 & 7.83 & 7.86 & 8.06 & \\
\hline measured ......... & 6.55 & 6.71 & 7.11 & 7.18 & 7.75 & 7.83 & 8.00 & \\
\hline
\end{tabular}


The unit cell dimensions are given in Table 1. The data presented in this table shows no correlation between the individual cell parameters and parent chemical composition. However, the unit cell volume seems to be a reflection of the ratio of $\mathrm{Mn} / \mathrm{Fe}$. Fig. 2 shows the atomic ratio $100 \cdot \mathrm{Mn} /(\mathrm{Mn}+\mathrm{Fe})$ plotted against the unit cell volume. The unit cell volume increases with increasing $\mathrm{Mn}$ (decreasing $\mathrm{Fe}$ ). The greatest $100 \cdot \mathrm{Mn} /(\mathrm{Mn}+\mathrm{Fe})$ ratio occurs at a volume of approximately $424 \AA^{3}$. The $\mathrm{Nb} / \mathrm{Ta}$ ratio also seems to affect the unit cell volume somewhat. Specimens 5, 12, and 14 for example, contain increasingly higher ratios of $\mathrm{Nb} / \mathrm{Ta}$ and relatively the same ratio of $100 \cdot \mathrm{Mn} /(\mathrm{Mn}+\mathrm{Fe})$, yet differ in each unit cell volume by approximately $1-2 \AA^{3}$.

Figure 3 represents the average of all the diffractograms examined. The vertical height is exaggerated to exemplify the visual intensity relation between the peaks. These diffractograms show distinct differences between columbite (including tantalite, $\mathrm{A}$ in the Fig. 3) and manganotantalite (B). The 200, 400, and 600 peaks increase greatly in samples rich in $\mathrm{Mn}$ and Ta. The 112 is weak, but present in the $\mathrm{Mn}$ and $\mathrm{Ta}$ rich material and is not present in the columbite or tantalite. The 110 peak may or may not be present in the columbite or tantalite, but when present, it is very weak. In manganotantalite it is usually stronger. The $711+512$ peak is not present in columbite or tantalite but is present in manganotantalite, as is the 421 peak. The 023 peak is more prominent in the manganotantalite.

The question of variation of X-ray data with chemical analysis has been speculated on by several authors. Nickel, et al. (1963) state that there is probably a gradation from a completely

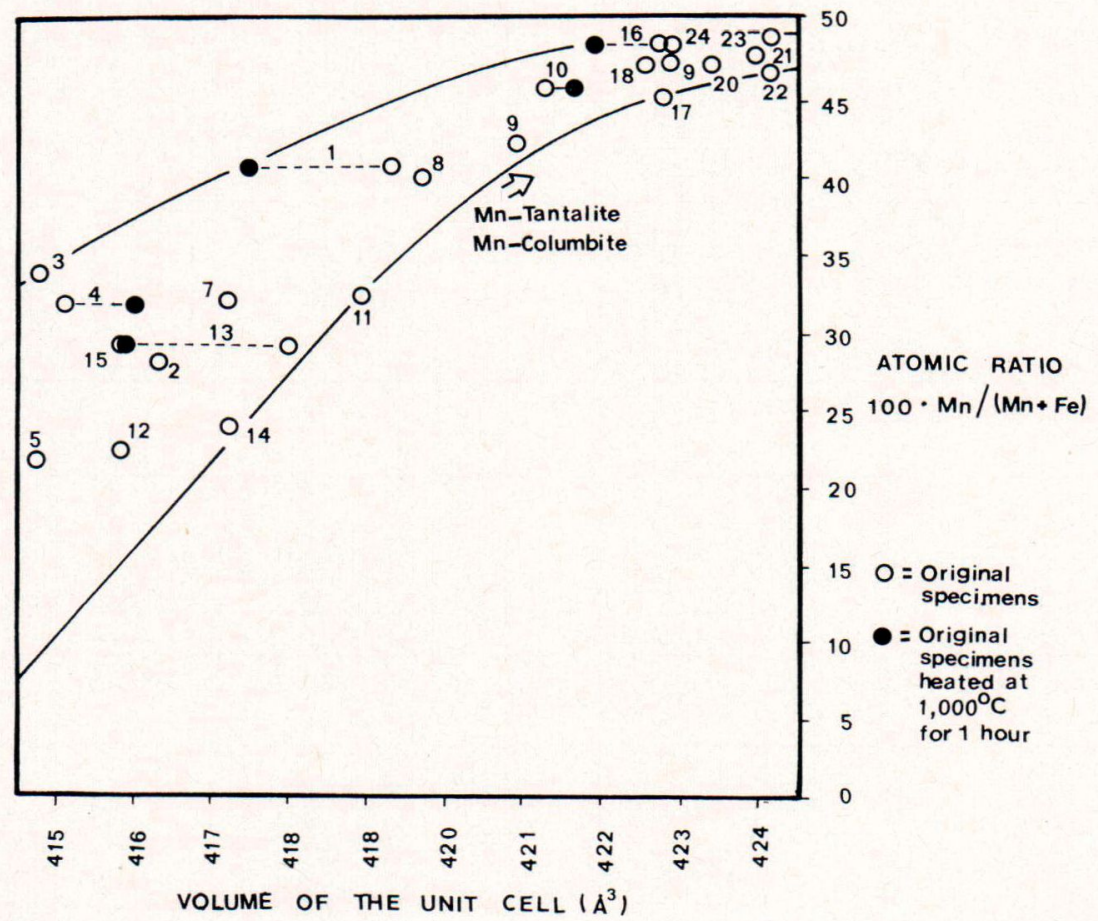

Fig. 2. Atomic ratio $100 \cdot \mathrm{Mn} /(\mathrm{Mn}+\mathrm{Fe})$ plotted against the volume of the unit cell of specimens Nos. $1-5$ and $7-24$. Five of those original specimens (Nos. 1, 4, 10, 13, and 16) were, in addition, heated at $1000^{\circ} \mathrm{C}$ for 1 hour and the results are also plotted. 
ordered end-member (columbite-tantalite) to a fully disordered one (pseudo-ixiolite). The degree of order of the columbite structure shows up on the diffraction pattern by the disappearance of reflections with $h \neq 3$ and in particular of reflections 200 and 110, the main indicators of ordered columbite. Komkov (1970) also agrees that columbite may have different degrees of disoder and this, he adds, is reflected by a change in the unit cell parameters. Greater ordering increases parameter $a_{0}$ and decreases $c_{0}$ and, therefore, affects the $a_{o} / c_{0}$ ratio. Also, with a decrease of order the intensity of peaks with $\mathrm{h} \neq 3$ decrease. In ordered columbite the $a_{0} / c_{0}$ ratio with the setting conformable with Pbcn varies, depending on composition, from 2.825 to 2.839 . In completely disordered columbite $\mathrm{a}_{\mathrm{o}} / \mathrm{c}_{\mathrm{o}}$ equals 2.76 to 2.77. The specimens used to determine the $a_{0} / c_{o}$ ratios were synthetic. Komkov further states that, in addition to the order-disorder relation affecting the diffraction pattern, the ratios of $\mathrm{Fe}$ to $\mathrm{Mn}$ and $\mathrm{Nb}$ to $\mathrm{Ta}$ also affect the pattern. Considering the previous literature and analys- ing the specimens examined in this paper for an $\mathrm{a}_{\mathrm{o}} / \mathrm{c}_{\mathrm{o}}$ ratio shows that almost the entire orderdisorder range is represented in these specimens (Table 1). Samples Nos. 16 and 17 (manganotantalite) are the most disordered $\left(\mathrm{a}_{\mathrm{o}} / \mathrm{c}_{\mathrm{o}}=\right.$ 2.769) and sample No. 21 (manganotantalite) is the most ordered $\left(a_{\circ} / c_{o}=2.838\right)$. Only a total of 5 specimens were found in an ordered condition (Nos. 20, 21, 22, 23, and 24), and all of those were manganotantalite. A closer look at all the specimens fails to adequately distinguish a correlation, under natural conditions, between chemical composition and order-disorder tendencies.

According to Nickel et al. (1963) disordered columbite may be changed to ordered columbite by heating. Komkov (1970) advocates a temperature of $1,000^{\circ} \mathrm{C}$ for roughly one hour. Six of the original specimens (Nos. 1, 4, 10, 13, 16, and 20) investigated were ground to powder, mixed with charcoal (to absorb the oxygen present), placed in a sealed quartz tube, and heated according to the recommendation by Komkov (ibid.). X-ray work was then carried out on the specimens.
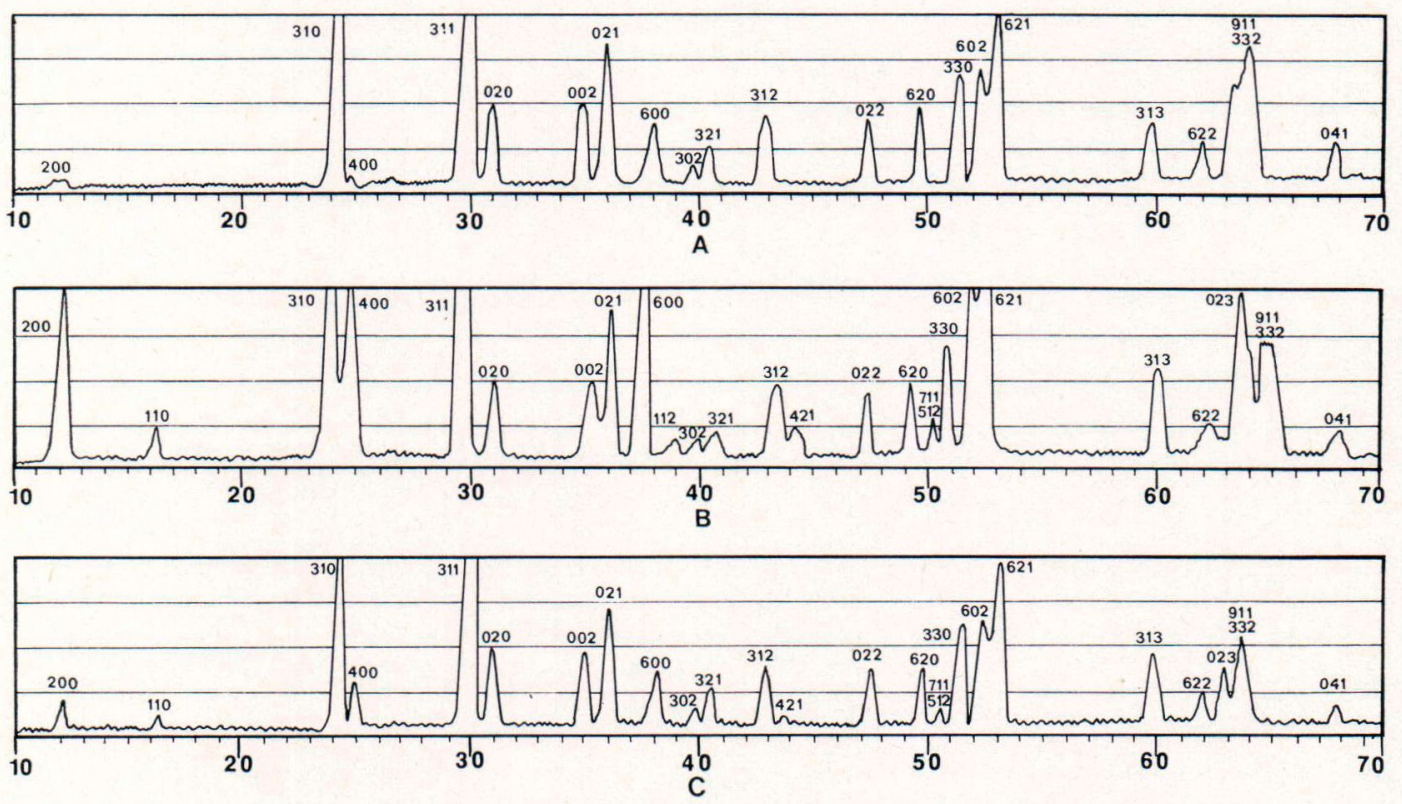

Fig. 3. (A) Columbite or tantalite, disordered form. (B) Mn-tantalite, ordered form. (C) Originally disordered columbite or tantalite (dia. A) heated to $1000^{\circ} \mathrm{C}$ for 1 hour, to form ordered columbite or tantalite. 
Comparing the unit cell parameters (Tables 1 and 2) of the natural disordered columbite specimens (Nos. 1, 4, 10, 13, and 16) and their heated counterparts shows a distinct change in the unit cell dimensions. The $\mathrm{a}_{\mathrm{o}}$ dimensions have increased and the $c_{o}$ dimensions have decreased. The $a_{0}: c_{0}$ ratio therefore has increased into the magnitude proposed by Komkov (ibid.) for ordered columbite. The $b_{0}$ dimensions have primarily increased also. The unit cell volume decreases for samples Nos. 1, 13, and 16 and increases in sample No. 4 and increases slightly in sample No. 10. These new unit cell volumes were plotted in Fig. 2. They fall inside the given boundaries indicating that the $\mathrm{Mn} / \mathrm{Fe}$ ratio is significant in determining the unit cell volume, whether the specimen be ordered or disordered.

Sample No. 20 (manganotantalite) which was in a natural ordered form, was subjected to the identical heat treatment as the disordered specimens. The $\mathrm{a}_{0}$ and $\mathrm{b}_{0}$ dimensions remained virtually unchanged. The $c_{0}$ dimensions, however,

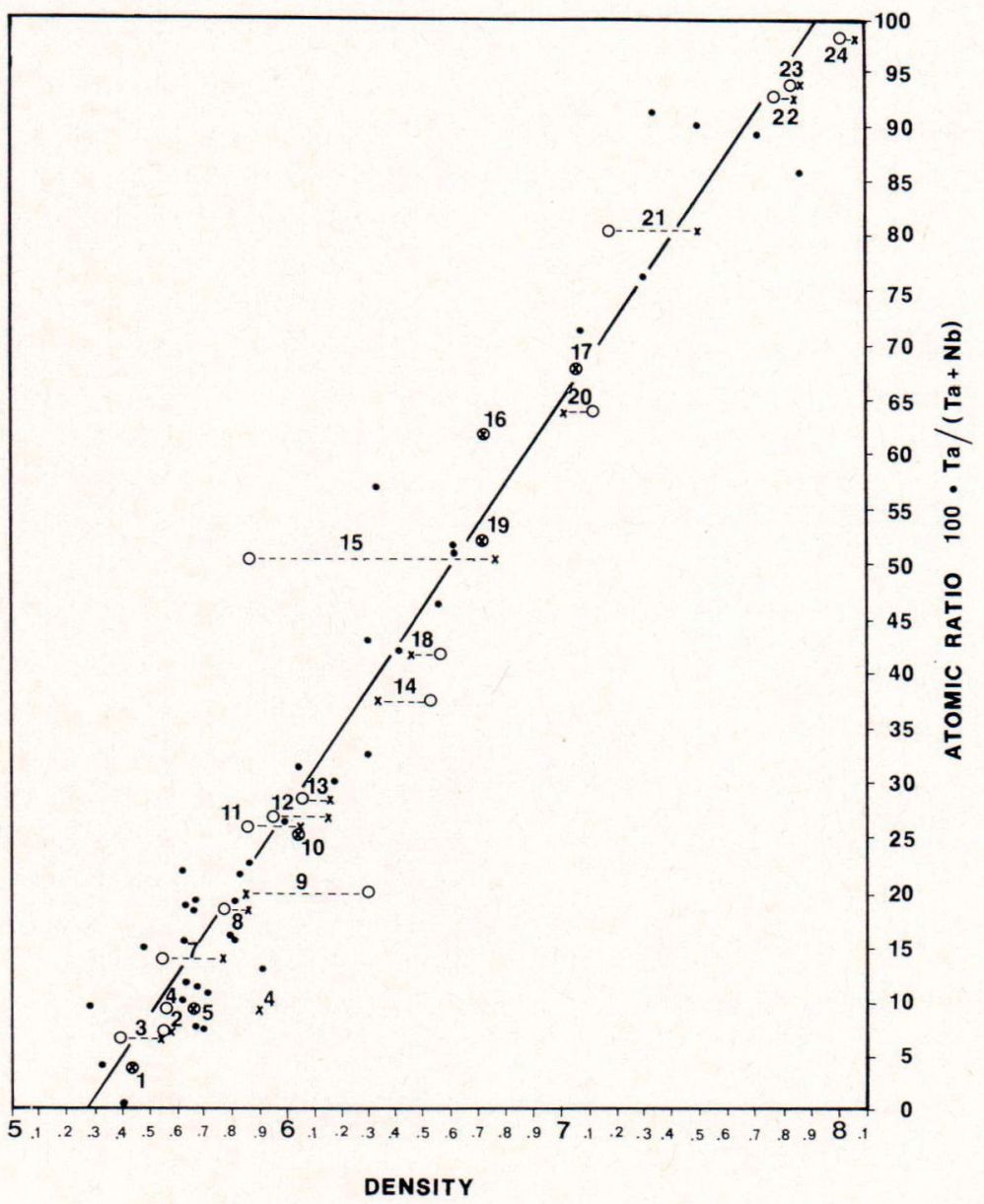

- measured value $\times \quad$ calculated value

Fig. 4. Atomic ratio $100 \cdot \mathrm{Ta} /(\mathrm{Ta}+\mathrm{Nb})$ plotted against density of specimens Nos. $1-5$ and $7-24$. Both measured and calculated values are given for those specimens. In addition, some 37 columbite-tantalite specimens gleaned from the literature (unnumbered) have been added for comparison. 
TABLE 2.

Unit cell parameters of specimens Nos. 1, 4, 10, 13, 16 and 20, identical to those in TABLE 1 , heated for one hour at $1000^{\circ} \mathrm{C}$

\begin{tabular}{l|c|c|c|c|c|c}
\hline & 1 & 4 & 10 & 13 & 16 & 20 \\
\cline { 2 - 7 } & & & 16 & & \\
$\mathrm{a}_{0}(\AA) \ldots \ldots \ldots \ldots \ldots$ & 14.340 & 14.327 & 14.401 & 14.332 & 14.409 & 14.410 \\
$\mathrm{~b}_{0}(\AA) \ldots \ldots \ldots \ldots$ & 5.747 & 5.735 & 5.757 & 5.736 & 5.755 & 5.756 \\
$\mathrm{c}_{0}(\AA) \ldots \ldots \ldots \ldots$ & 5.065 & 5.064 & 5.085 & 5.059 & 5.088 & 5.168 \\
$\mathrm{~V}\left(\AA^{3}\right) \ldots \ldots \ldots \ldots$ & 417.4 & 416.1 & 421.6 & 415.9 & 421.9 & 428.7 \\
$\mathrm{a}_{0} / \mathrm{c}_{0} \ldots \ldots \ldots \ldots$ & 2.832 & 2.829 & 2.832 & 2.833 & 2.832 & 2.788 \\
$\mathrm{a}_{0}= \pm .01(\AA), \mathrm{b}= \pm .005(\AA), \mathrm{c}_{0}= \pm .005(\AA)$ & & &
\end{tabular}

increased considerably. This caused the $a_{o} / c_{0}$ ratio to decrease to such an extent that the structure according to the previous definition, became disordered.

The X-ray diffractograms (Fig. 3-C) of the original natural disordered specimens changed significantly upon reorganization into ordered specimens. There is an obvious tendency of these specimens to conform to the ordered manganotantalite diffraction pattern. The only peak present in the diffractogram of the ordered manganotantalite and not in that of the heat treated columbite or tantalite specimens is the 112. Komkov (1970), in experiments with synthetic specimens, found this peak in the diffractograms of a $\mathrm{MnTa}_{2} \mathrm{O}_{6}$ specimen, but not in that of a $\mathrm{MnNb}_{2} \mathrm{O}_{6}$ specimen. This, then, is found to conform with his experiments.

The 110,421 , and $711+512$ peaks are present, but very weak, in the re-ordered heat treated specimens studied in this paper and were not, with minor exception, in the original disordered specimens. The 200,400 , and 600 peaks are much more prominent in the heat treated specimens, than in the original ones. The 023 has become somewhat more prominent and the 021 somewhat less prominent in the heat treated specimens.

\section{Density}

Densities of small grains of the specimens (Nos. $1-5$ and $7-24$, reference Table 1) weigh- ing from approximately 13 to $23 \mathrm{mg}$. were determined by means of a Berman balance ( $\pm .01 \mathrm{mg}$.). A steromicroscope was used to detect any visible impurities. The values determined range from 5.39 for columbite to 8.00 for Mn-tantalite (Table 1), which agree closely with previously published limits.

The atomic ratio $100 \cdot \mathrm{Ta} /(\mathrm{Ta}+\mathrm{Nb})$ (Fig. 4) of some 60 specimens (Nos. $1-5$ and $7-24$ plus 37 specimens gleaned from the literature) have been plotted against density (measured). An estimate of the $100 \cdot \mathrm{Ta} /(\mathrm{Ta}+\mathrm{Nb})$ ratio may be obtained using the equation:

$$
\frac{100 \cdot \mathrm{Ta}}{\mathrm{Ta}+\mathrm{Nb}}=37.209 \cdot \mathrm{d}-195.4
$$

where $d$ is the density. The equation was calculated from the plotted points in Fig. 4.

A correlation between the observed densities of the specimens examined in this paper and the calculated densities (obtained from the chemical analysis and the unit cell volume) of the same specimens reveal, in some cases, a large discrepancy which is probably caused by analytical errors. These calculated densities are also plotted in Fig. 4 and correlated to their measured-density counterparts.

Acknowledgements - The author is indebted to the Dept. of Geology and Mineralogy, University of Helsinki, Finland, for guidance throughout the study and to Dr. O. v. Knorring, Dept. of Earth Sciences, Leeds University, U. K., for graciously providing the specimens examined in this paper. 


\section{REFERENCES}

DANA, J. D. and E. S. (1946) The system of Mineralogy. Ed. by C. Palache, H. Berman and C. Frondel. Vol. I, 7th ed. John Wiley and Sons, Inc., N. Y.

KNORring, O. v. (1970) Mineralogical and geochemical aspects of pegmatites from orogenic belts of equatorialand southern Africa. Pp. 157-184 in African Magmatism and Tectonics, Kennedy vol., ed. by T. N. Clifford and I. G. Gass. Oliver and Boyd, Edinburgh

Knorring, O. v., Sahama, Th. G. and SaAri, E. (1966) A note on the properties of manganotantalite. C. R. Soc. géol. Finlande 38: 47-50.

Komkov, A. I. (1970) Relationship between the X-ray constants of columbites and composition. Dokl.
Acad. Sci. U.S.S.R. Earth Sci. Sect. 195 (2): $432-436$ (in Russian).

Laves, F., Bayer, G. and Panagos, A. (1963) Strukturelle Beziehungen zwischen den Typen a- $\mathrm{PbO}_{2}, \mathrm{FeWO}_{4}$ (Wolframit) und $\mathrm{FeNb}_{2} \mathrm{O}_{6}$ (Columbit), und über die Polymorphie des $\mathrm{FeNbO}_{4}$. Schweiz. Min. Petr. Mitt. 43: 217.

Nickel, E. H., Rowland, J. F. and McAdam, R. C. (1963) Ixiolite - a columbite substructure. Am. Min. 48: $961-979$.

Manuscript received, February 12, 1975. 